\title{
The Method of Marxism Popularization in the university
}

\author{
Xiao-jie Zhu ${ }^{1}$,Li Shu ${ }^{2}$ \\ ${ }^{1}$ The Central Institute for Correctional Police,Baoding, China \\ ${ }^{2}$ HeBei College of Science and Technology ,Baoding,China
}

\begin{abstract}
College is the main position to training builders for socialism in China, and its purpose of Marxism popularization in the college is to continuously improve the Marx doctrine self-cultivation of college student, make the Marx doctrine belief firmly. But the there are some problems such as the propagation mode single, and the content is out dated in the current process of Marxism Popularization in College. Faced up the new requirements of the new era, we should promoting university Marxism Popularization by setting up the special organization, perfecting teaching content and improving education method.
\end{abstract}

Keywords: The Marxism; Popularization; Method

\section{INTRODUCTION}

The report of Eighteen Congress of the Communist Party of China emphasizes that "promoting Marxism Sinicizing, modernization, and popularization. Use the theory of socialist Chinese characteristics to arm the whole Party and educate the people unremittingly, implementing the project to study and develop Marxist theory deeply, establishing innovation system of philosophy and social science, promoting the system of theories of socialism with Chinese characteristics into the teaching material, the class, and the mind "The socialist core value system is one of the mental strength of guiding our party and nation construct the cause of socialism with Chinese characteristics. To promote the popularization of the Marx doctrine is not only reflected in the construction of the socialist core value system, embodied in the all construction of our country and all development aspects. China is a socialist country that guided by the Marx doctrine, the Marx doctrine has come to
China since the October revolution, the Communist Party of China lead the people to continue to inherit and carry forward the spirit of keeping up with times of Marxism, lead the people of all ethnic groups to learn the Marx doctrine and practice of Marx doctrine, it had a major significant impact on people's production and life, at the same time, it makes the relevant science theory and advanced thought root in the people's hearts deeply. In addition, during the process of Marx theory guiding us in the construction of Chinese characteristic socialism practice, the Communist Party of China has always adhere to the Marx doctrine theoretical quality that keeping pace with the times, combined with the reality of our country, has formed the Marx doctrine in china, then come into being the Chinese characterization of Marxism. The struggle and construction experience nearly a hundred years tells us, the Marx doctrine must be grasped in the broad masses of people, and only in this way can we realize its popularization and play its biggest role. If the masses cannot recognized the Marx doctrine deeply in their own heart, study the Marx doctrine seriously or treat the Marx doctrine as their own ideological content, then the development of Marx doctrine will be corresponding limit in the our country. "Marxism popularization is propagating Marxism through lively form, with an easy to understand language, and make the Marxism be understood, accepted and mastered by masses of people, then put it into the core thought of their own, and transformed as the guide to action in life and work consciously". [1]

Colleges is the main battlefield of promoting the Marxism popularization in our country. There are a lot of ideological and political educator and the young college student who undertake the task of building socialism with 
Chinese characteristics. Itis also the place where the fresh thinking and prosperous culture active, the young college students are the main object of the higher education in our country, when they go to the society, they will be the main force in the cause of building socialism China characteristics. Young college students how to understand the Marxism, whether believe in the Marxism faith has a great significance for the development of the whole society.Guaranteeing the particularization of the Marx doctrine in colleges is the important part of promoting the people learn, identify and act Marxism in the whole society. For the colleges and universities, "the Marxism popularization is actually an interactive process of teachers convey the Marxism to the students on their own initiative and the students accept the Marx doctrine actively." ${ }^{[2]}$ In the process of interaction, the teachers' active communication and the students' learning initiative are two indispensable factors in the educational activities. As educators, teachers conduct the relevant content and principle of the Marx doctrine to the students in the classroom, and they should use the various and colorful teaching methods to explain the complicated principle of the Marx doctrine, and they are also required to choose a new way that easy to understand to teaching contents and guide the young students more receptive to the content as much as possible. In the educational activities, young college students are in the object, but also have considerable subjectivity of individuals, although they accepted teachers conduction content in the classroom, this kind of acceptance is not passive, but selective, they always learn the content based on the a certain foundation that their theory of knowledge structure themselves. Then, they accept of the teacher teaching content in an individual's position. At last, they will realize the internalization into practice behavior.Practicality, nationality, and temporal is the important feature of the Marx doctrine, advancing with the times is the central theoretical qualities of the Marx doctrine. It is precisely because we never give up the combination of Mark doctrine and actual situation that we can create the unprecedented development in Chinese society at present.

\section{Some problems of Marxism popularization in the university}

\subsection{The transmission mode is traditional, it cannot attract young college students}

First of all, the main way to promoting Marxism popularization is the course of ideological and political theory, the instructors convey the spirit of the meeting or printing and distributing the material in the present universities, which is so traditional. The traditional communication method use the rigid traditional teaching language, and the words are more serious format, lack of interest. The society that majority of young people live in, has all kinds of cultural life rich and colorful Internet information, cyber source is very extensive, if the learning content is as dull as ditch water, it is difficult to mobilize the enthusiasm of young college students who is lively and full of curiosity for new things.Secondly, the route of transmission of Marxism popularization is more official and less personal emotional care, such as the Party organizations at all levels, the school newspaper or campus network or the activities of Communist Youth League. On the one hand, it leads that the dissemination of the contents is more serious. On the other hand, the participation of students are not high enough, and we cannot achieve better education objective. Because this kind of mode of transmission is affected by the college party organizations at all levels of supervision and management, so the contents from this kind of dissemination is most of the party and government events news, sometimes, it is so far from the students normal life, which leads students to lose the interest for this kind of mode of transmission of the information, they pay little attention on these information, so the education effects of the contents cannot work.Finally, the traditional mode of communication has formed the students on the Marx doctrine stereotypes impression, that they think the Marx doctrine is the study of various documents, is "false", and it does not fit for their real life, and therefore they will be tired with the Marx doctrine. The Marx doctrine of strict standard of language "is not suitable with the awakening of individual consciousness in the 
current social, and it often disparaged called 'machine language' to not to be popular" ${ }^{[3]}$

\subsection{Influence of social thoughts on College Marxism popularization}

With the reform and opening up, the degree of openness in China is expanding constantly, continuing to strengthen cooperation and communication with foreign China in the economy makes us to achieve a fast development. At the same time, all kinds of social thoughts began to swarm into our country along with the deepening of opening, "money worship", "and hedonism" and "pragmatism" thoughts are in vogue. The rapid economic development also brings with some problems for example, the gap is too large, the employment of college graduates and other social problems. After the reform and opening up, the university students lose confidence in the Marx doctrine. They think that the Marx's faith cannot bring substantial benefits, so it leads many college students treat the Marx doctrine by the utilitarianism view, they cannot find the great value of it, but think that the Marxism is useless. If majority of the college students insist that wrong thought, it will be difficult make the inner recognition of Marxism.Most of the time, the evaluation standard of college education quality is the employment rate height. The evaluation standard of a student is the career success or money accumulation, which leads many universities to relax for further promotion of the Marxism popularization. They began to doubt the correctness of the Marxism, many students even questioned the rationality of Chinese socialism. They abandoned the faith of Marx doctrine in, gradually become blind to pursuit of the so-called success. The continuous influx of various trends of social thought, put forward a huge challenge for the Marxism popularization in universities, but we believe that the correctness and direction of Marx doctrine, look at these social trends with a critical view, utilizing and exerting its beneficial effect Fully.

\section{The great significance of the Marxism popularization in college}

\subsection{It is the need to be firm students' Marxism faith}

The object of Mark doctrine popularization in Colleges and universities is the young college students, they accept the higher education, which is the center power in the socialist modernization construction in china. First, college students need the influence of the Marx doctrine. The social environment is so complicated, and the impact of various values continue to impact on the China young college students. The students, after high school, learn in the university where help them establish correct world, views on life and values. If there is no correct thought guiding them, they will fall into a wrong path. Continuing to promote the popularization of the Marx doctrine is to make contemporary college students can find their own spiritual ascription and insist the firm belief of Marxism when facing the complex social environment, and they should always maintain a positive state of mind to strive for the realization of China Dream. In addition, the Marx doctrine cannot keep up with the times development in China without the learning and promotion of young people. The Marx doctrine can be popularization better by their learning and practicing for the Marx doctrine.

\subsection{Faced with the great challenges for the college Students' ideological and political education brought by the complex network}

With the development of network technology, people has been affected by Internet deeply. By the end of 2009, "China's Internet users reached 3 million, ranking first in the world, under 35 years of age accounted for more than $80 \%$ of the total number of Internet users, college and above the high educated group over $90 \%$ people are online." ${ }^{[4]}$ Compared with the traditional dissemination channel, the network information spreads fast and contains a large amount of information. But at the same time, the Internet information is a mixed bag. The fundamental task of Ideological and political education is the "using the Marx 
Lenin doctrine, Mao Zedong thought, Deng Xiaoping theory to educate the mass of people, cultivating the new socialist people have ideals, morality, culture, discipline." ${ }^{[5]}$ To promote the popularization of the Marx doctrine is one of the important content to realize the ideological and political education, and it is also the inevitable choice to cope with the new challenge for the ideological and political education in era of network. It is the important guarantee to realize the basic task of higher education.

The fundamental task of our higher education is cultivating the builders for socialist construction, " higher education should first solve the core problem is to 'what person to cultivate 'and 'cultivate people for whom' " ${ }^{[6]}$ The main target of promoting the Marxism popularization in colleges and universities is to enable the college students to establish a firm belief in Marxism, guide their own life and learning with the Marx's scientific world outlook and methodology. The present society of our country has entered the crucial period of reform, although he uneven economic development leads to the large gap between rich and poor, the phenomenon of college students employment difficultly still exists, we cannot deny the great achievements of China's reform and opening up nearly forty years. The Marx doctrine guides us to continue moving forward in the economic, political, cultural, ecological and many other construction, we must ensure its popularization successfully, and ensure that every college students will step into the society are able to treat themselves and the use the society in a developing view. It really proves that the task of our higher education is completed.

\subsection{The popularization of Marxism divorcing between "first class" and "the second class"}

Promoted in colleges and universities, the popularization of the Marx doctrine of "the first class" mainly refers to the specialized teaching of ideological and political theory courses, which are taught by full-time teachers in Colleges and universities. But the ideological and political theory is limited by objective conditions, and most of the related courses are taught in large class. Teachers can hardly appeal deeply to the students' emotion, to understand and listen to students' feelings. With continuous innovation and changing depth in the teaching mode and content, it is also very difficult to have better effect on the popularization of Marxism. "The second classroom" refers to some practical activities composed by the Communist Youth League, the instructor, students, student organizations and other units of the organization. Through leading and guiding students to participate in social practice related to ideological and political guidance, this type of organization closer to students, can find problems, communicate and exchange time by time. But "the second classroom"- the counselor and community are lack of necessary communication with the subject of education-full-time teachers in ideological and political theory courses. It is a major problem to be solved urgently that how to combine theory "indoctrination" in class and communication in practice with students.

\section{The Method of Marxism Popularization in the university}

\subsection{Strengthening the team construction of the Marxism popularization}

The promotion of Marx's popularization in universities rely mainly on the full-time teachers of ideological and political and the department work for students, the full-time teachers of Ideological and political plays a major role in spreading the Marxism theory. Teachers will teach some basic knowledge of the Marxism theory to the students in the politics theory class, the ideological and political education teachers with high quality can always use the straightaway, humorous language to explain many Marx principle clearly. As our Marx's successors, they always have this ability, Deng Xiaoping has said that "Whether a white cat or a black cat, a good cat catches mice." He use the lively and vivid language to explain a major proposition of socialist market economy. In addition, the high level Marx doctrine population educators can combine theory with practice, combining reality, use the Marx theory to solve the real problem in our life. Therefore, "the college and universities 
must establish a team including the initiator, political staff and student backbone for Marxism Popularization, they all have firm faith, perfect skills, and functional supplementation". [7]

\subsection{Improving the mechanism to promote the Marxism popularization}

At first, a scientific planning mechanism is very important. The content we will learn and promote must be planned and arranged reasonably, what kind of content is suitable for students? What kind of content can attract students after adjusting? We should find the answer to the question. Secondly, we must have certain security mechanism and innovative mechanism. Schools should set aside special funds and manpower support for the Marx doctrine of popularization, we must innovate some activity ways that more students love to learn and join basic on the traditional promotion mod, add the spirit of Marxism popularization into the colorful practical activities. Finally, constructing the assessment and evaluation mechanism. To promote Marxism popularization is a long-term work that need insist all the time, constructing a scientific and reasonable evaluation mechanism, making the stage evaluation and summation evaluation timely, we should find problems, and solve problems according to the actual work. Effective work should be rewarded, but the bad work must be punished.

\subsection{See the student as the beginning, adhere to the people-oriented}

In a long term, the popularization of Marxism was not carried out easily in college, because neglect students inner emotional needs, lessen education content less than target, and educational methods are too traditional stereotypes. We haven't really recognized and accepted. Compulsory indoctrination popularization of Marxism is not the Marx doctrine vulgarization, narrowing from up to down. But in college students' position, it pays attention to actual demand of university students the survival and development. It makes college students see, hear, and realize the Marx doctrine mastery of College students." ${ }^{[8]}$ The process of people's ideological and moral form through the conversion process, emotion, knowledge, and meaning. For the letter, from the most basic cognition to finally into moral action, it is a process of internalization to externalization from the outside, and internalization is the foundation at the same time in outside to continuously consolidate and firmly improves quality. In the course of the Marx doctrine popularization in universities, we have been in the pursuit of the external education continue to stimulate students' motivation to pursuit of value identity. So emotion and faith will transform into a certain behavior, and "self-worth and self-intrinsic need my perfect development is the internal decision power" [9] as having a certain personality and social individual students, they are including spiritual, material and other aspects of demand. We know the advance of the popularization of Marx doctrine in the process, which must adhere to the students as the breakthrough point. They really understand the students' needs that the Marx doctrine guide their thoughts. We need to use different way to help them understand and learn the Marx doctrine. Adhere to the people-oriented in the course of the Marx doctrine in the popular, namely, "requires students to value and evaluation subject to college students, with the likeness, satisfaction and acceptance as the evaluation measures to the popularization of University Marxism. Is it right? Effective important scale"[10]

\section{CONCLUSION}

Marx's popular process has a long way to go, it is not a moment to be complete, and we must firmly upholding guiding position of the Marx doctrine in our nation. Starting with the young college students, promoting popularization and development of the Marx doctrine continuously, if majority of young students, the object of higher education grasp the essence of Marxism firmly, they will learn the guiding ideology deeply and solve the actual problems with the relevant principles and spirit of Marxism. When they step into the society and go to work later, they will use the practical action to influence and lead more people around them to learn the Marx doctrine. 


\section{Reference:}

[1][2][9] Xiao Rong. Promoting College Marxism Popular from the Angle of Acceptance [J]. Modern education science, p.26, p.27, 2011 (4).

[3]Pan Kun .Marxism Popularization in University under the Background of Network [J].Journal of National Academy of Education Administration, p.70, 2011 (5).

[4]Feng Gang. The Issues of Colleges and Universities Promote Marxism popularization [J]. Journal of Ideological and theoretical education, p.35, 2009 (9): media.

[5]Chen Wanbai, Zhang Yaocan. Principles of Ideological and Political Education (Second Edition), Higher Education Press, p.79, 2007.7,

[6]Fan Xiaoqiang, Ma Ning. Treating Marxism
Popularization in Universities and Colleges from Three Dimensions [J]. Studies in ideological educational, p.37, 2013(4).

[7]Peng Ensheng. The Path of Contemporary Marx in Popularization in Colleges and Universities [J]. Theory and practice of education, p.35, 2012 (6)

[8]Wang Yong. The Influence of Ethos on Marxism Popularization in College and Countermeasure [J]. Journal of Chang Zhou University (social science edition), p.26, 2011 (7).

[9] Shang Guangmei. On the Way of Realizing Marxism Popularization in Colleges and Universities [J].Journal of Northeast Normal Universities (Philosophy and Social Science), p.28, 2012 (5). 